\title{
Academic Leadership through E- education in India
}

\author{
Abdul Karim Siddiqui \\ Assistant Professor, Dept. of Computer Applications, Awadhoot Bhagwan Ram P.G. College Anpara- Sonebhadra (U.P.)
}

\begin{abstract}
The reorientation and up gradation of civilized groups can be invoked by introducing formal and informal education system, the vocational system, open and distance programs, social libraries, and through mass media. The methods of grasping education have been transforming. With the advent of Computer, the advancement of education has made us global pupil who gain knowledge from diverse sources and servers. One of the useful applications of Internet is E-education. It institutes digital classroom anywhere anytime. The term E-learning is widely accepted for E-education. Also terms like online education, virtual education, Internet-based education, web-based education, and education via computer-mediated communication are common in higher education system. Today we have many career options besides becoming an engineer or a doctor. Online learning has been better utilized in the corporate world for training activities, than at the individual level for educational purposes. The Academic excellence of Higher education institutions can be maintained and upgraded through $E$ - education system. The Government of India has now been considering the use of information and communication technologies (ICT) as a means for new emerging programmes and courses.
\end{abstract}

Keywords: E-education, E-learning, Higher Education in India, Education Research, Distance Learning, Teaching, Computer-Based Education, On-line Education, Learning, Virtual-Classroom.

\section{Introduction}

Education has accompanied civilization throughout the many centuries. For long time teachers have been teaching and applying applied knowledge to fulfill and to satisfy the expectations of their students. The methods and the tools they applied to assure the need of proper communication have continuously been changing. The time has been changed and the information and technology has afforded it new shape and shine. Now every hand has electronic gadget and it has become essential element of our daily lives. The youth today, learns by tactics. His steps are not bound only for one or two educational institutions. He wants to learn from vast space and this idea confines him towards rest of the world. With the developments of countries like India, the cost and usage of higher education system is no doubt a big factor to lead whole world. The governments are making efforts to provide basic education to everyone. The scholars, doctors and engineers are assets for any nation. And these assets are explored by providing higher education.

\section{The Education}

Education is the process by which societies deliberately transmit their accumulated information, knowledge, understanding, attitudes, values, skills, competencies and behaviours across generations.

The aim of providing worldly education is to balance the four factors- ecological, social, economic and environmental. These bring sustainability in our lives. The ultimate goal of providing education is to incorporate discipline in our actions. An educated citizen may help in nation- building. Education anytime, anywhere and to anyone should be our priority. It should not be restricted with age, place or group of people. Learning is a life time process. Unless we change our society into a learning society, we will not be in position to handle the odd situations. If we provide such a system that augment people's capabilities to resolve the life issues, it will be real service for mankind. Education can change society when it aims for last man of system.

\section{A. E-education or E-learning}

E-learning or E-education is electronic learning, and typically this means using a computer to deliver part, or all of a course whether it is in a school or college, part of your mandatory business training or a full distance learning course. E-learning includes numerous types of media that deliver text, images, audio, animation, and streaming video. The "E" letter in E-education may also be applied for the favorable meaning like - "exciting, energetic, enthusiastic, extended, excellent, and educational" in addition to "electronic".

\section{B. E-education is characterized by}

- The separation of teachers and learners i.e. No face-toface education or physical classroom environment.

- The influence of an educational organization to promote and offer variety of online courses and programs.

- The use of a computer network to present or distribute some educational content i.e. Presenting e-content through internet.

- The provision of two-way communication via a computer network so that students may benefit from communication with each other, teachers, and staff through teleconferencing, video-chat etc.

\section{Key advantages of E-education include:}

- Improved open access to education, including access to full degree programs

- Better integration for non-full-time students, particularly in continuing education,

- Improved interactions between students and instructors,

- Provision of tools to enable students to independently solve problems,

- Acquisition of technological skills through practice with tools and computers.

- No age-based restrictions on difficulty level. 


\section{International Journal of Science and Research (IJSR) \\ ISSN (Online): 2319-7064 \\ Index Copernicus Value (2013): 6.14 | Impact Factor (2015): 6.391}

\section{E- education in India}

We are in digital age. Students have many career options besides traditional diversions. Though traditional courses such as engineering, medicine, and chartered accounting are still in high demand, IT, Management and other new courses are emerging as new career options in this competitive environment. These career options have emerged as a result of changing economic trends across the globe. These trends open new windows for education. Today in India, students adopt technology as a medium for attending classes remotely, either through VSAT((Very Small Aperture Terminal), a technology that offers connectivity without geographical or locational constraints.) or through virtual classrooms on the Web. The National Mission on Education through Information and Communication Technology (NMEICT) has been ideated the benefit of all the learners in Higher Education Institutions in any time any where mode. It seeks to bridge the digital divide, i.e. the gap in the skills to use computing devices for the purpose of teaching and learning among urban and rural teachers/ learners in Higher Education domain.

E- education or online -education, gradually evolved from the concept of distance education. In India, over the years, distance education has continuously adopted advancements in digital technology. The use of multimedia has rapidly changed the two-way communication, teacher-learner

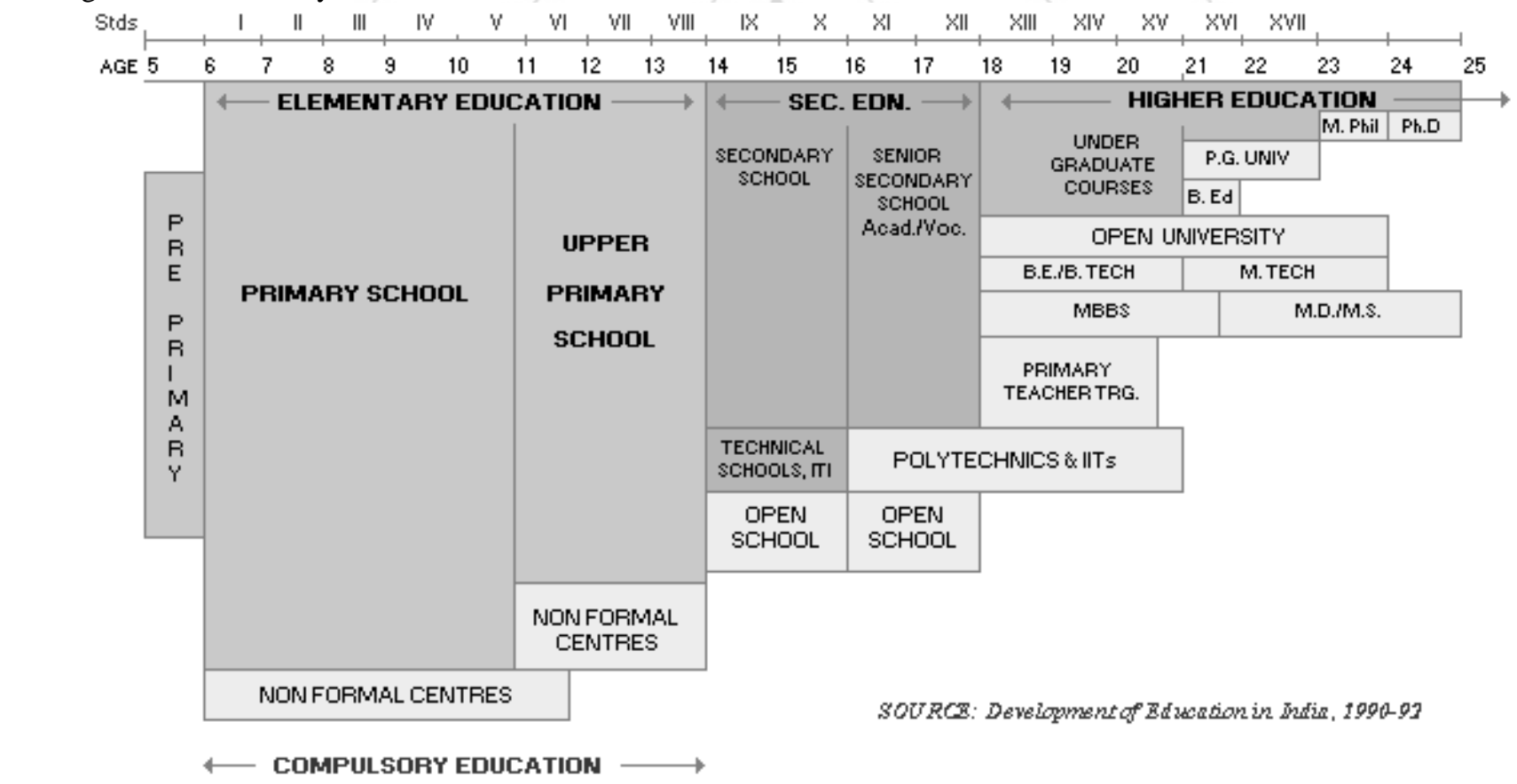

Figure 1: Development of Education in India interactivity, the pedagogy, and quick content distribution in respect to time and space. The use of the Internet in India is increasing in both mobile devices and PCs. Governments are stay focused to lead country at global platform. Electronic gadgets are now the part of our daily lives. Today, the age group from 15-24, most heavily use these networking devices. $80 \%$ of enrolled students in Higher education come from this domain. This huge amount of people can be utilized by policy makers for making distance education more effective and helping e-learning by invoking new demanding vocational programmes. All India Council of Technical Education (AICTE) reported that there are near about 4,600 vocational institutions that offer degrees, diploma and post-diploma in engineering, pharmacy, architecture, hotel management, infrastructure, technology, town services and others by 2013. More than 1.7 Million students were enrolled in these schools.

According to the University Grants Commission, New Delhi, total enrolment in Science, Medicine, Agriculture and Engineering crossed 6.5 Million in 2010. The number of women choosing engineering has more than doubled in last one decade. The Open Institutions like IGNOU are contributing to maintain the range of higher education system within and outside the country. Fig-1.
E-education Systems are designed to effectively promote education and training. The programme delivery and learner support services are now shifting towards correspondence to multimedia. Open Learning institutions are now providing short term programmes for specialized courses. Many foreign universities have started their programmes on-line with collaboration with local universities which provides a global form of education system.

\section{E. E-education in Higher Education}

A per Ambient Insight report- July 2011, India has the highest projected growth rate (about 57\%), followed by
China and Malaysia in the worldwide market for self-paced e-learning products and services. The growth rate in the combined Asia region is robust at $28.4 \%$. Total enrolment in higher education in India has been estimated to be 28.56 million with 15.87 million boys and 12.69 million girls. Girls constitute $44.4 \%$ of the total enrolment. Distance enrolment constitutes $12.5 \%$ of the total enrolment in higher education, of which $39.9 \%$ are female students.

These figures are really propelling and encourage us to expand the web of E-learning in country. The enrollments of students have been growing much faster in last few years in 


\section{International Journal of Science and Research (IJSR) \\ ISSN (Online): 2319-7064}

Index Copernicus Value (2013): 6.14 | Impact Factor (2015): 6.391

new emerging disciplines such as Management and IT \& Computers. Fig.-2. Also other traditional disciplines and subjects have shown growth by incorporating onlineeducation in higher education.

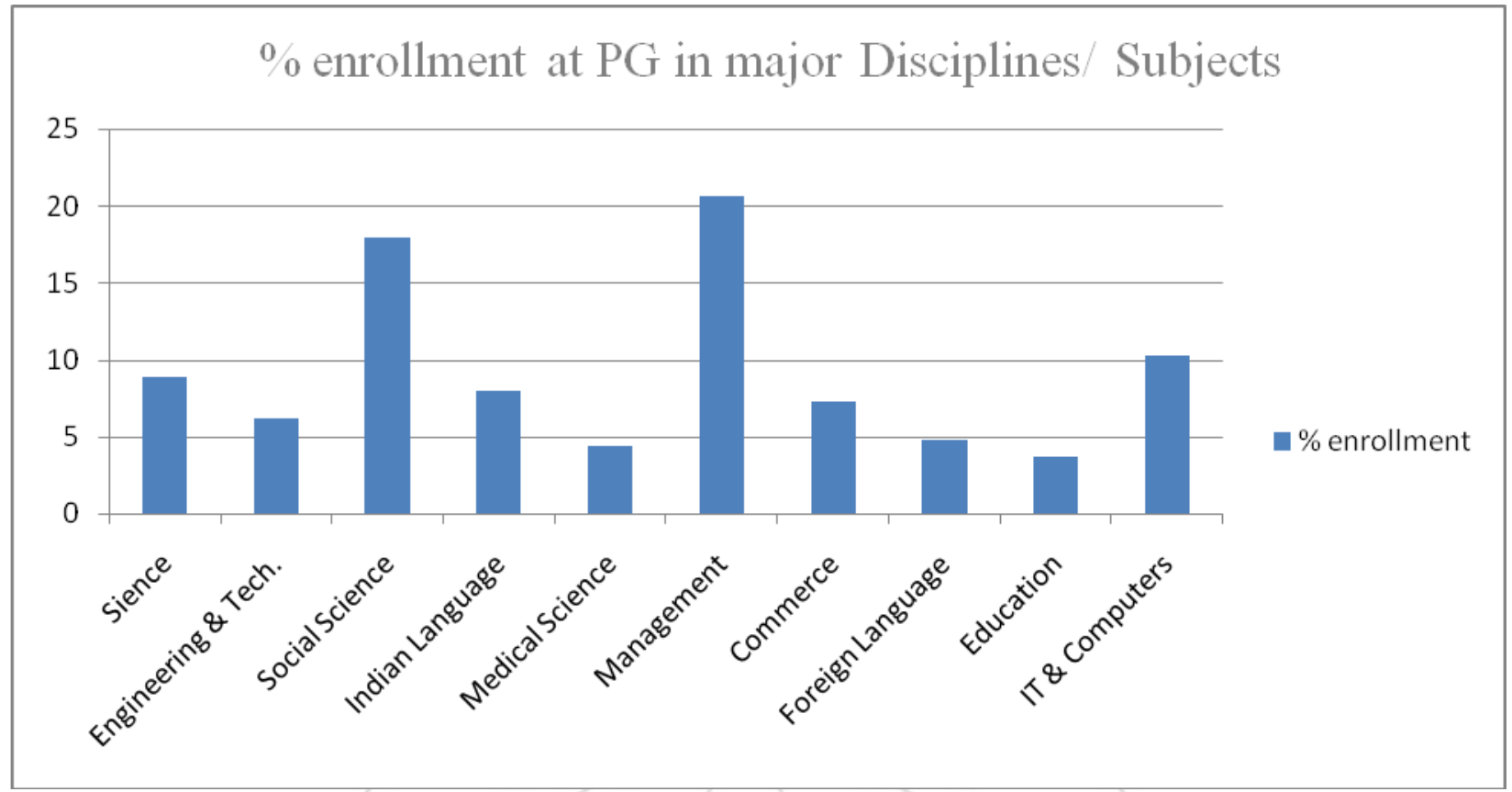

Figure 2: As per MHRD- Dept. of Higher Education- AISHE, 2011-12

F. E- Education and ODL

Online education in India is part of the Open and Distance Learning (ODL) philosophy. ODL systems have evolved over time. The general academic programmes offered by ODL institutions include:

- Doctoral Programmes

- Bachelor's Degree and Master's Degree Programmes

- Computer and Library \& Information Sciences

- Journalism, Communication and Creative Writing

- Health, Nutrition and Child Care

- Engineering \& Rural Development

- Education \& Distance Education

- Management \& Tourism Studies

- Women and Youth Development

- Area Specific Awareness \& Manpower Development Programmes

\section{Result and Discussions}

The education system in India has largest networks of institutions. More than 1 million schools and 18,000 higher education institutions are spreading its knowledge in service of the country. Half of the population of country is augmenting the target market for education and related services. 12.5 million Users are adding each year in Internet. Internet accelerates online education that is why with the revolution in information \& technology, E-education is overtaking conventional education system. E-Learning has revolutionized the educational sector. It has changed our perspective and it meant for knowledge and skill acquisition altogether. Today, digitalized system has made it more impressive and more effective for millions of learners. Millions of students and office workers are using e-Learning to earn their degree, build upon their knowledge base and develop new skills. Now the highly uneven distribution of education between urban and rural India, and between private and government institutions does not make it very tough for rural students to find admission to good universities. In this way, E- Learning through distance programs/ online programs avails for better education and career enrichment services at higher level.

The concept of Meta University where students can pursue their course in three State-run universities and benefit from their expertise and infrastructure simultaneously and the planning of HRD Ministry towards taking active steps to incorporate firmly e-learning within the mainstream educational system, assures for academic advancement. MHRD Ministry is also determined of operationalize Council of Industry-Higher Education Collaboration (CIHEC) to identify initiatives to promote research, mobilize resources, develop market-ready manpower and enhance employability.

\section{Conclusion}

Without a large number of quality institutions, no nation will be able to create knowledge societies. Online-learning initiates to provide supplementary education and pools the gap of academic leadership in higher education. The HRD Ministry is also taking active steps to further e-learning within the mainstream educational system. Although Distance Education Council (DEC), is co-ordinating 13 State Open Universities and 119 institutions of correspondence courses in conventional universities, distance education augmented through online access may be the answer to the stressed education system in India. The government of India has established many institutions such as National Mission on Education through Information and Communication Technology (NMEICT), National Video Server of the National Programme on Technology Enhanced Learning (NPTEL), National Informatics Centre (NIC) and 
Centre for Development of Advanced Computing (C-DAC) for supporting and maintaining the E-education in the country.

\section{References}

[1] "Characteristics of the Successful Online Student". Gc.maricopa.edu. 2004-11-17.

[2] "Networked Collaborative Learning: social interaction and active learning", Woodhead/ Chandos Publishing Limited, Cambridge, UK.

[3] "India Country Summary of Higher Education". World Bank.

[4] "'Higher Education", National Informatics Centre, Government of India". Education.nic.in. Retrieved 2010-09-01.

[5] "Latest Statistics on Indian Higher Education". DrEducation.com.

[6] Indian Standard Classification of Education (InSCED), 2014

[7] "e-Learning trends in India"; (www.wiziq.com)

[8] "The Worldwide Market for Self-paced eLearning Products and Services: 2010-2015 Forecast and Analysis"; ambientinsight.com

[9] "New Education Policy on the anvil: Smriti"; thehindu.com; August 4, 2014

[10] "Development of Education in India", Dept. of Education, MHRD - India 1990-92

[11] “Annual Report 2012-13, Dept. of School Education \& Literacy Dept. of Higher Education”, MHRD- India.

[12] "Report of the CABE - committee on Autonomy of Higher Education Institution”, MHRD, June,2005.

\section{Author Profile}

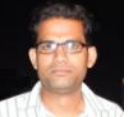

The author is a lecturer (Computer Science) at Awadhoot Bhagwan Ram P.G. College Anpara, Sonebhadra (U.P.) - accredited 'B' by NAAC. He is the Steering Committee Co-ordinator - NAAC A \& A process and IQAC at the Institution. He has 4 years of academic and 2 years of IT Industry experience. 